\title{
RELATIONSHIP BETWEEN THE NUMBERS OF ADULT MALE CATCHES ON PHERMONE TRAPS AND PERCENTAGE OF BOLL INFESTATION FOR COTTON BOLLWORMS IN MIDDLE EGYPT. \\ El-Kady, H. A. ${ }^{1}$; E. M. Mohamed ${ }^{2}$; E. F. EL - Khayat ${ }^{3}$ and S. A. Hosni ${ }^{2}$ \\ ${ }^{1}$ Economic Entomology Dept., Fac. of Agric., Damietta University, Egypt. ${ }^{2}$ Sids Agric. Res. Station, Plant Protection Res. Institute, ARC, Giza, Egypt. \\ ${ }^{3}$ Fac. of Agric. , Moshtohor, Benha University, Egypt.
}

\section{ABSTRACT}

Under field conditions of Beni- Suef Governorate , field studies were carried out at the farm of Sids Agriculture Research Station during 2006, 2007 and 2008 cotton seasons to study the monitoring the first appearance and populations of adult males of both pink bollworm, Pectinophora gossypiella (Saunders) and spiny bollworm, Earais insulana (Boisd.) by using Delta pheromone baited traps.

The average number of male moths of $P$. gossypiella per trap / week during the period from April till September during the 2006, 2007 and 2008 cotton seasons, In the first season 2006, had five peaks of abundance in $5^{\text {th }}$ May, $15^{\text {th }}$ June, $14^{\text {th }}$ July, $4^{\text {th }}$ August and $8^{\text {th }}$ September. In the second season 2007, also five peaks were observed. These peaks were occurred on $10^{\text {th }}$ April, $24^{\text {th }}$ April, $12^{\text {th }}$ June, $24^{\text {th }}$ July and $21^{\text {st }}$ August While in the third season 2008, four peaks were observed on $1^{\text {st }}$ May, $29^{\text {th }}$ May, $31^{\text {st }}$ July and $4^{\text {th }}$ September.

The average number of male moths of $E$. insulana per trap / week during the periods extending from March $17^{\text {th }}$ till September $15^{\text {th }}$, March $27^{\text {th }}$ till $4^{\text {th }}$ September and April $3^{\text {rd }}$ till September $18^{\text {th }}$ during the 2006, 2007 and 2008 seasons, respectively. In the first season 2006, four peaks of spiny bollworm were observed in $21^{\text {st }}$ April, $30^{\text {th }}$ June, $11^{\text {th }}$ August and $15^{\text {th }}$ September. In the second season 2007 , five peaks were observed in $24^{\text {th }}$ April, $8^{\text {th }}$ May, $12^{\text {th }}$ June, $24^{\text {th }}$ July and $28^{\text {th }}$ August. While in the third season 2008, four peaks observed in $1^{\text {st }}$ May, $31^{\text {st }}$ July, $4^{\text {th }}$ September and $18^{\text {th }}$ September.

The combined effect of the two main weather factors on the changes in the population activity of the pink bollworm moths explained by the percentages of variance of the two tested weather factors were significant during 2006 and high significant during 2007 season, respectively but in 2008 season, was insignificant. The correlation between the spiny bollworm population and the weather factors Max. and Min. temperature and average relative humidity, it is obvious that a simple positive correlation coefficient between the average number of captured male moths in sex pheromone traps and max. temperature was found, but this correlation was insignificant during 2006 and 2007 seasons and significant $0.38(P=0.08)$ in 2008 growing season. The combined effect of the two main weather factors on the changes in the population activity of the spiny bollworm moths explained by the percentages of variance of the two tested weather factors which was significant during 2006, but in 2007 and 2008 planting seasons it was insignificant.

\section{INTRODUCTION}

Cotton is the most important fiber crop all over the world. In Egypt, cotton is a very important crop that is cultivated mainly for fibers to use in 
industry and seeds for oil which is of great value. Cotton plants in Egypt have been attacked with numerous pests from planting till harvest, including sap sucking pests, cotton leaf worms and cotton bollworms, causing great damage to plants and crop yield. All the plant parts is attacked, but the most serious pests primarily attack the fruiting portions; buds, flowers and green bolls, reducing both quantity and quality of the harvested fibers and seeds, during the late season. Cotton plants greatly suffer from infestation with pink bollworm, Pectinophora gossypiella (Saunders) and spiny bollworm, Earais insulana (Boisd.). Pheromone trapping can be used to detect early infestations of an insect pest, monitor established populations and assist in the timing of pesticide applications in relation to the build-up of populations to dangerous levels (Jutsum and Gordon, 1989). Toscano et al. (1974) reported significant reductions in the number and cost of insecticide applications when treatments for bollworms control were based on male moth trap catches as compared to automatic five to seven day insecticide spray schedules. The use of pheromones in the management of $E$. insulana and $P$. gossypiella is studied and discussed by earlier workers (Mclaughlin and Mitchel, 1982 and Kumar and Devraj Urs, 1991). The seasonal variation of the insect is important information necessary for careful timing of applications of control measure. Hence the present study was undertaken to develop a pheromone based monitoring system for fluctuations of bollworms population build-up. This will facilitate proper timing of insecticidal spray and other control strategies for the management of bollworms. This study was conducted to determine the relationships between adult population in pheromone traps and infestation ratio by larvae in cotton bolls and their correlation with weather parameters.

\section{MATERIALS AND METHODS}

Experiments were carried out at Sids Research Station, Beni- Suef Governorate during 2006, 2007 and 2008 cotton growing seasons. The experimental area was cultivated with the Egyptian cotton variety Giza 80.

\section{Monitoring the adult males of both pink and spiny bollworm populations by pheromone traps.}

The changes in the activity of the pink and spiny bollworm moths were studied during three successive cotton growing seasons. Two-delta sticky pheromone traps baited with two capsules containing $1 \mathrm{mg}$ of gossyplure were placed in the experimental field to observe the population of the pink bollworm. In addition, one delta sticky trap and one funnel trap baited with two capsules for spiny bollworm males. The traps were fixed at different positions in the experimental field and changed each weak. The trap catch was checked each weak and the number of trapped males was recorded during the period of March till $15^{\text {th }}$ September in the three seasons. Pheromone capsules were replaced by new ones every two weeks according to Othman et al. (2000), who found that the degradation of both gossyplure pheromone isomers (ZZ - and ZE - 7,11 - hexadecadienyl acetate) was fast 
after 14 days of hanging; the residue half- life $\left(R L_{1 / 2}\right)$ of the pheromone was 40 days after application under field conditions.

Simple correlations between the trapped male moths of $P$. gossypiella and $E$. insulana and the infestation percent and larval content was calculated in the same week according to Al- Beltagy et al. (1995). Linear equation regressions: $\left(Y=x^{2}+b x+a\right)$ were calculated for each density of traps at each season.

Where:

$\mathrm{Y}=$ Number of young larvae,

$\mathrm{b}=$ regression factor

$\mathrm{x}=$ No. of moths $/$ trap/ week.

$\mathrm{a}=$ constant

2. Determination of cotton bolls infestation by both bollworms larvae.

For assessing the infestation of cotton bolls by pink and spiny larvae, 100 green bolls were collected weekly till the end of each season at random from both diagonals of the inner square area of each treatment according to the method of Shaaban and Radwan (1974). Samples were kept in tightly closed cloth tissue bags and transferred to the laboratory for examination. The bolls were inspected and dissected to count the number of larvae population density of both bollworms as well as infestation percent of bolls at the same day of sampling.

\section{Weather parameters.}

The records of the atmospheric daily maximum, minimum temperature and relative humidity for the years 2006, 2007 and 2008 were obtained from the Central Laboratory for Agriculture and Land Reclamation, Dokki, Egypt.

\section{RESULTS AND DISCUSSION}

\section{Population dynamics of cotton bollworms.}

To be able to suggest the appropriate times to spray for bollworms, it was essential to study of their population dynamics under the field conditions of Beni- Suef Governorate. Field studies were carried out at the farm of Sids Agriculture Research Station during 2006, 2007 and 2008 cotton seasons to monitor the first appearance and populations of adult males of both pink and spiny bollworms using Delta pheromone baited traps.

\subsection{Pink bollworm (PBW):}

Data presented in Tables (1,2 and 3) and illustrated in Fig.(1, 2 and 3 ) show the average number of $P$. gossypiella male moths per trap / week during the period from March1 $7^{\text {th }}$ to September $15^{\text {th }}$, March2 $7^{\text {th }}$ to September $4^{\text {th }}$ and April $3^{\text {rd }}$ to September $18^{\text {th }}$ during 2006, 2007 and 2008 cotton seasons, respectively. In the first season, 2006 five peaks were recorded number of males / trap / week, the first peak occurred on $5^{\text {th }}$ May and reached 41.33 males / trap per week. The second peak occurred at the mid of June and reached 45.00 males / trap / week. The third peak occurred on the $14^{\text {th }}$ July and reached 59.5 males / trap/ week. While the fourth and fifth peaks were found on the $4^{\text {th }}$ August and $8^{\text {th }}$ September and reached to 44.5 and 75.5 males/ trap/ week, respectively. In the second season 2007, also 
five peaks were observed. These peaks were occurred on $10^{\text {th }}$ April, $24^{\text {th }}$ April, $12^{\text {th }}$ June, $24^{\text {th }}$ July and $21^{\text {st }}$ August and reached $16.00,33.60,51.50$, 59.00 and 79.5 males / trap/week, respectively. While in the third season 2008 , four peaks were observed. These peaks occurred on $1^{\text {st }}$ May, $29^{\text {th }}$ May, $31^{\text {tt }}$ July and $4^{\text {th }}$ September and reached $34.5,59.0,53.5$ and 108.5 males / trap / week, respectively. This data agreed to a great extent with the previous findings of many investigators. Hamid and Al-Beltagy (1995) showed the presence of 4 peaks each allowed to a PBW generation. The first peak (the highest one) appeared on May $9^{\text {th }}$ indicating the emergence of the suicide generation. The second peak (the lowest one) appeared on $10^{\text {th }}$ June, indicating PBW flower generation (the small generation which infested flower buds). The third and fourth peaks (the intermediate peaks) appeared by July 28 and August 29, pointed out to the two boll infesting generation of PBW. In addition, Abdel - Hamid et al. (1999) mentioned that the P. gossypiella had 5 generations during the whole season, but three generations occurred during the cotton season. Ismail et al. (2002) used the delta pheromone traps to estimate the flight activity of $P$. gossypiella moths in cotton fields through three successive cotton seasons 1993, 1994 and 1995 in Menoufia Governorate, Egypt. Results indicated that five peaks were detected in 1993 and 1994, but in 1995, the number of male moths caught by the sex pheromone trap peaked 6 times. Mohamed (2004) mentioned that the $P$. gossypiella had 4- 5 peaks of male moths / trap / week during the cotton season.

\subsection{Spiny bollworm (SBW).}

Data presented in Tables (1,2 and 3) and illustrated in Figures (1, 2 and 3 ) showed the average number of male moths of $E$. insulana per trap / week during the periods extending from March $17^{\text {th }}$ till September $15^{\text {th }}$, March $27^{\text {th }}$ till $4^{\text {th }}$ September and April $3^{\text {rd }}$ till September $18^{\text {st }}$ during the 2006, 2007 and 2008 seasons, respectively. The average number of males / trap / week of the 2006 cotton season presented in Table 1 and illustrated in Fig. 1, four peaks of spiny bollworm were observed. The first peak occurred on the $21^{\text {st }}$ of April (7.20 males / trap / week) and marked to the first generation which attacked cotton plants during the first week of May and lasted up to late May. The second peak occurred on the $30^{\text {th }}$ of June and reached 24.50 males / trap/ week. While the third and fourth peaks were found on the $11^{\text {th }}$ of August and $15^{\text {th }}$ of September and reached to 53.5 and 96.31 males/ trap/ week, respectively. In the second season 2007, five peaks were observed. These peaks occurred in $24^{\text {th }}$ April, $8^{\text {th }}$ of May, $12^{\text {th }}$ of June , $24^{\text {th }}$ of July and $28^{\text {th }}$ August and reached 24.0, 26.5, 32.0, 33.0 and 80.5 males / trap/week, respectively. While in the third season 2008, four peaks observed. These peaks were occurred on $1^{\text {st }}$ May, $31^{\text {st }}$ of July, $4^{\text {th }}$ of September and $18^{\text {th }}$ September. It reached 23.0, 64.5, 72.5 and 94.5, respectively.

Moawad (1974) and Barania (1979) found that late-planted cotton was the most infested with spiny bollworm. Moreover, El- Zanan (1987) found that the highest average number of larvae / 100 cotton green bolls and the highest percentage of bollworm infestation were recorded when cotton was sown in late April as compared with that sown in late March or mid- April. 
Hossain et al. (1999) studied the number and duration of spiny bollworm, $E$. insulana field generations during three seasons 1993, 1994 and 1995 in

Gharbia \& Kafr El- Sheikh Governorates. Their results revealed the presence of six overlapping generations during the investigation period in each of the three tested localities. Also, Tawfik (2002), reported that 5 clearly interval periods of $E$. insulana activity from the $2^{\text {nd }}$ week of May to the $2^{\text {nd }}$ week of September during the 2000 and 2001 cotton seasons.

Table (1): The average number of males caught / trap / week, percent of infestation and the number of larvae in 100 cotton bolls for $P$. gossypiella and $E$. insulana in cotton fields during season,2006.

\begin{tabular}{|c|c|c|c|c|c|c|c|c|}
\hline \multirow{4}{*}{$\begin{array}{l}\text { Inspection } \\
\text { dates }\end{array}$} & \multirow{3}{*}{\multicolumn{2}{|c|}{$\begin{array}{c}\text { Av. No. of males } \\
\text { /trap/week }\end{array}$}} & \multicolumn{6}{|c|}{2006 season } \\
\hline & & & \multirow{2}{*}{\multicolumn{2}{|c|}{$\%$ infestation }} & \multicolumn{4}{|c|}{ No. of larvae /100 bolls } \\
\hline & & & & & \multicolumn{2}{|c|}{$1^{\text {st }}$ instar } & \multicolumn{2}{|c|}{ All instars } \\
\hline & PBW & SBW & PBW & SBW & PBW & SBW & PBW & SBW \\
\hline 17-Mar & 9.51 & 0.50 & 0 & 0 & 0 & 0 & 0 & 0 \\
\hline 24-Mar & 17.60 & 1.60 & 0 & 0 & 0 & 0 & 0 & 0 \\
\hline 31-Mar & 10.17 & 1.75 & 0 & 0 & 0 & 0 & 0 & 0 \\
\hline 07-Apr & 12.90 & 1.10 & 0 & 0 & 0 & 0 & 0 & 0 \\
\hline 14-Apr & 22.31 & 2.18 & 0 & 0 & 0 & 0 & 0 & 0 \\
\hline 21-Apr & 27.00 & 7.20 & 0 & 0 & 0 & 0 & 0 & 0 \\
\hline 28-Apr & 34.00 & 2.14 & 0 & 0 & 0 & 0 & 0 & 0 \\
\hline 05-May & 41.33 & 1.30 & 0 & 0 & 0 & 0 & 0 & 0 \\
\hline 12-May & 30.51 & 1.40 & 0 & 0 & 0 & 0 & 0 & 0 \\
\hline 19-May & 21.09 & 1.50 & 0 & 0 & 0 & 0 & 0 & 0 \\
\hline 26-May & 18.33 & 3.50 & 0 & 0 & 0 & 0 & 0 & 0 \\
\hline 02-Jun & 27.56 & 2.00 & 0 & 0 & 0 & 0 & 0 & 0 \\
\hline 09-Jun & 37.50 & 8.00 & 0 & 0 & 0 & 0 & 0 & 0 \\
\hline 16-Jun & 45.00 & 5.00 & 1 & 1 & 1 & 1 & 1 & 1 \\
\hline 23-Jun & 43.00 & 9.50 & 3 & 2 & 3 & 2 & 3 & 2 \\
\hline 30-Jun & 45.50 & 24.50 & 2 & 1 & 2 & 1 & 3 & 1 \\
\hline 07-Jul & 35.50 & 14.00 & 3 & 2 & 3 & 1 & 3 & 2 \\
\hline 14-Jul & 59.50 & 3.10 & 4 & 1 & 4 & 0 & 4 & 1 \\
\hline 21-Jul & 22.50 & 3.50 & 5 & 1 & 5 & 1 & 5 & 1 \\
\hline 28-Jul & 32.50 & 11.88 & 7 & 0 & 4 & 0 & 7 & 0 \\
\hline 04-Aug & 44.50 & 25.50 & 11 & 4 & 4 & 4 & 11 & 4 \\
\hline 11-Aug & 38.50 & 53.50 & 8 & 3 & 6 & 1 & 8 & 3 \\
\hline 18-Aug & 31.50 & 21.50 & 17 & 4 & 11 & 4 & 17 & 4 \\
\hline 25-Aug & 29.50 & 46.60 & 20 & 9 & 8 & 5 & 27 & 12 \\
\hline 01-Sep & 46.50 & 35.50 & 40 & 11 & 17 & 6 & 53 & 8 \\
\hline 08-Sep & 75.50 & 74.50 & 53 & 24 & 20 & 5 & 79 & 24 \\
\hline 15-Sep & 65.50 & 96.31 & 59 & 18 & 28 & 13 & 60 & 18 \\
\hline$r$ & & & $0.64^{*}$ & $0.86^{* *}$ & $0.58^{*}$ & $0.81^{\text {** }}$ & $0.65^{*}$ & $0.87^{* *}$ \\
\hline $\mathrm{b}$ & & & 0.50 & 3.29 & 1.15 & 6.44 & 0.40 & 3.31 \\
\hline $\begin{array}{l}r=\text { Simple } c \\
{ }^{*}=\text { Signific } \\
\mathrm{PBW}=P . g c\end{array}$ & iella & & & & $\begin{array}{l}=\text { Regr } \\
=\text { Signi } \\
W=E .\end{array}$ & $\begin{array}{l}\text { sion co } \\
\text { cant at } \\
\text { sulana }\end{array}$ & $\begin{array}{l}\text { fficient } \\
\% \text { level }\end{array}$ & \\
\hline
\end{tabular}


El-Kady, H. A. et al.

Table (2) : The average number of males caught / trap / week, percent of infestation and the number of larvae in 100 cotton bolls for $P$. gossypiella and $E$. insulana in cotton fields during season,2007.

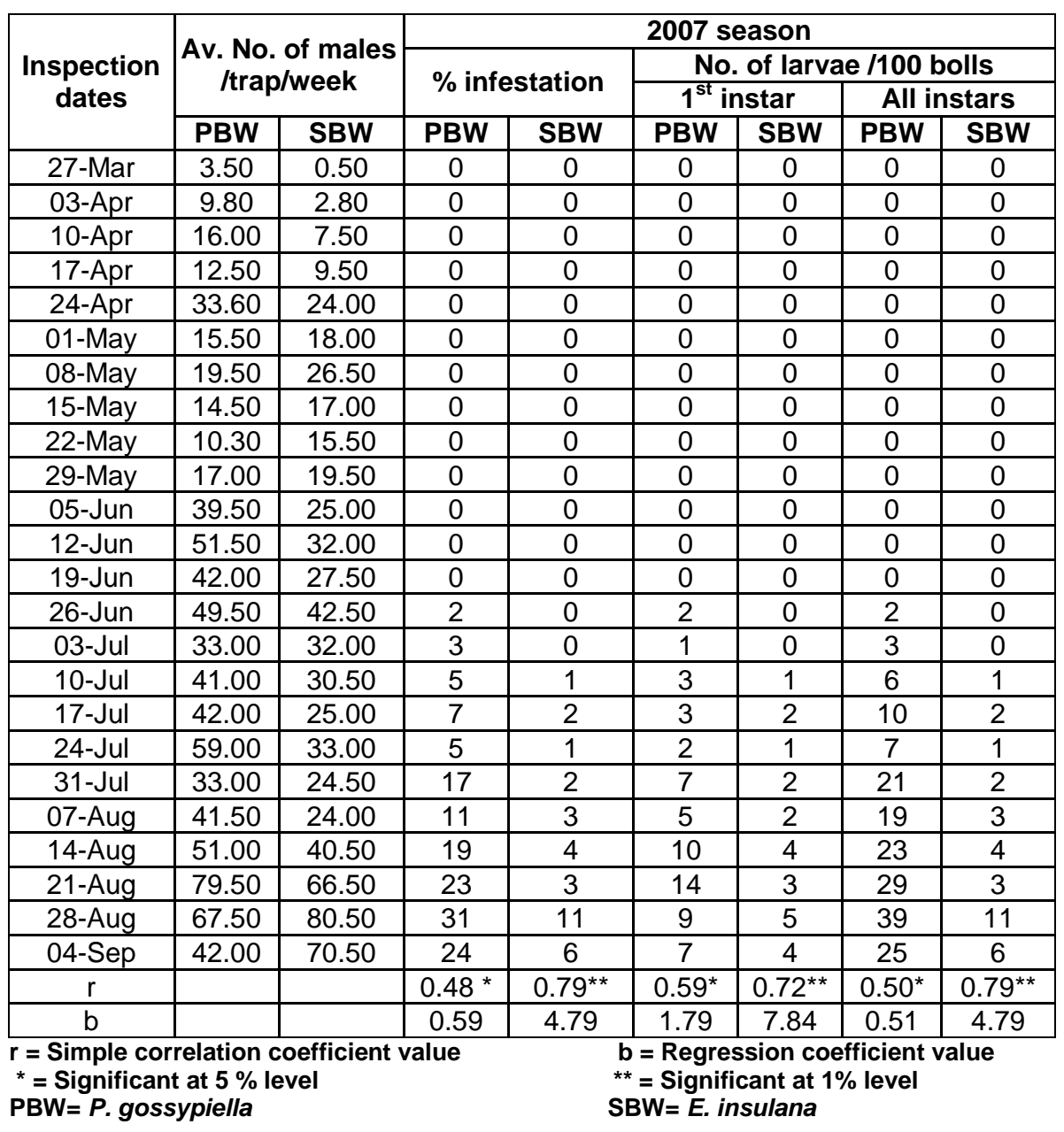


Table (3) : The average number of males caught / trap / week, percent of infestation and the number of larvae in 100 cotton bolls for $P$. gossypiella and $E$. insulana in cotton fields during season, 2008.

\begin{tabular}{|c|c|c|c|c|c|c|c|c|}
\hline \multirow{4}{*}{$\begin{array}{l}\text { Inspection } \\
\text { dates }\end{array}$} & \multirow{3}{*}{\multicolumn{2}{|c|}{$\begin{array}{l}\text { Av. No. of males } \\
\text { /trap/week }\end{array}$}} & \multicolumn{6}{|c|}{2008 season } \\
\hline & & & \multirow{2}{*}{\multicolumn{2}{|c|}{$\%$ infestation }} & \multicolumn{4}{|c|}{ No. of larvae /100 bolls } \\
\hline & & & & & \multicolumn{2}{|c|}{$1^{\text {st }}$ instar } & \multicolumn{2}{|c|}{ All instars } \\
\hline & PBW & SBW & PBW & SBW & PBW & SBW & PBW & SBW \\
\hline 03-Apr & 2.50 & 1.00 & 0 & 0 & 0 & 0 & 0 & 0 \\
\hline 10-Apr & 9.90 & 1.80 & 0 & 0 & 0 & 0 & 0 & 0 \\
\hline 17-Apr & 15.00 & 6.50 & 0 & 0 & 0 & 0 & 0 & 0 \\
\hline 24-Apr & 12.50 & 8.50 & 0 & 0 & 0 & 0 & 0 & 0 \\
\hline 01-May & 34.50 & 23.00 & 0 & 0 & 0 & 0 & 0 & 0 \\
\hline 08-May & 16.00 & 5.00 & 0 & 0 & 0 & 0 & 0 & 0 \\
\hline 15-May & 27.00 & 14.50 & 0 & 0 & 0 & 0 & 0 & 0 \\
\hline 22-May & 21.50 & 10.00 & 0 & 0 & 0 & 0 & 0 & 0 \\
\hline 29-May & 59.00 & 10.00 & 0 & 0 & 0 & 0 & 0 & 0 \\
\hline 05-Jun & 38.00 & 10.50 & 0 & 0 & 0 & 0 & 0 & 0 \\
\hline 12-Jun & 19.00 & 6.50 & 0 & 0 & 0 & 0 & 0 & 0 \\
\hline 19-Jun & 22.90 & 7.50 & 0 & 0 & 0 & 0 & 0 & 0 \\
\hline 26-Jun & 22.00 & 8.50 & 0 & 0 & 0 & 0 & 0 & 0 \\
\hline 03-Jul & 25.50 & 16.00 & 0 & 0 & 0 & 0 & 0 & 0 \\
\hline 10-Jul & 26.50 & 17.50 & 1 & 3 & 1 & 2 & 1 & 3 \\
\hline 17-Jul & 33.50 & 10.00 & 2 & 1 & 2 & 1 & 2 & 1 \\
\hline 24-Jul & 41.20 & 47.00 & 3 & 0 & 3 & 0 & 3 & 0 \\
\hline 31-Jul & 53.50 & 64.50 & 6 & 0 & 4 & 0 & 6 & 0 \\
\hline 07-Aug & 49.50 & 38.50 & 5 & 0 & 5 & 0 & 5 & 0 \\
\hline 14-Aug & 47.00 & 55.50 & 7 & 2 & 5 & 1 & 7 & 2 \\
\hline 21-Aug & 46.00 & 52.00 & 5 & 2 & 2 & 2 & 6 & 2 \\
\hline 28-Aug & 68.00 & 54.50 & 9 & 2 & 4 & 1 & 9 & 2 \\
\hline 04-Sep & 108.50 & 72.50 & 8 & 4 & 5 & 3 & 11 & 4 \\
\hline 11-Sep & 95.00 & 68.50 & 14 & 5 & 11 & 5 & 19 & 5 \\
\hline 18-Sep & 91.50 & 94.50 & 18 & 6 & 9 & 6 & 27 & 6 \\
\hline $\mathrm{R}$ & & & $0.87^{* *}$ & $0.68^{*}$ & $0.84^{* *}$ & $0.68^{*}$ & $0.85^{\star *}$ & $0.68^{*}$ \\
\hline B & & & 4.50 & 8.51 & 7.19 & 8.87 & 3.02 & 8.51 \\
\hline $\mathrm{PBW}=P \cdot g c$ & piella & & lue & & $\begin{array}{l}\text { Regre } \\
\text { Signifi } \\
N=E \text {. ir }\end{array}$ & $\begin{array}{l}\text { sion co } \\
\text { ant at } 1 \\
\text { sulana }\end{array}$ & $\begin{array}{l}\text { fficient } \\
\text { level }\end{array}$ & lue \\
\hline
\end{tabular}


El-Kady, H. A. et al.

Fig1

532 
J. Plant Prot. and Path., Mansoura Univ., Vol. 4 (6), June, 2013

Fig2 
El-Kady, H. A. et al.

Fig3 


\subsubsection{Relationship between the number of pink bollworm (PBW) male moths caught and the percentage of boll infestation.}

Field trails were carried out to evaluate the relationship between the number of pink bollworm, $P$. gossypiella male caught in the pheromone traps / week and percentages of infested green bolls in cotton fields sown on different dates in three successive cotton seasons, 2006, 2007 and 2008.

\section{In 2006 season.}

Data presented in Table (1) and illustrated in Fig. (4) indicated a positive and significant relationship between the average numbers of male moths of PBW caught in the pheromone traps and the rate of infested green bolls, the number of all larvae /100 bolls and the number of young larvae (first and second instar). The simple correlation coefficient values were 0.64 $(P=0.02), 0.65(P=0.001)$ and $0.58(P=0.02)$, respectively. The regression equation of average male moths and young larvae of PBW in cotton fields was $Y=0.011 X^{2}-0.8414 X+20.082$. (Fig. 4).

In 2007 season.

Data presented in Table (2) and illustrated in Fig. (4) indicated a positive and significant relationship between the average numbers of male moths of PBW caught in the pheromone traps and the rate of infested green bolls, the number of all larvae /100 bolls and the number of young larvae (first and second instar). The simple correlation coefficient values were 0.48 $(P=0.02), 0.50(P=0.001)$ and $0.59(P=0.02)$, respectively. The regression equation of average male moths and young larvae of PBW in cotton fields was $Y=0.007 X^{2}-0.5792 X+15.69$. (Fig. 4).

In 2008 season.

Data presented in Table (3) and illustrated in Fig. (4) indicated a positive and significant relationship between the average numbers of male moths of PBW caught in the pheromone traps and the rate of infested green bolls, the number of all larvae /100 bolls and the number of young larvae (first and second instar). The simple correlation coefficient values were 0.87 $(P=0.002), 0.85 \quad(P=0.001)$ and $0.84 \quad(P=0.002)$, respectively. The regression equation of average male moths and young larvae of PBW in cotton fields was $Y=-0.0013 X^{2}-0.256 X-5.355$.(Fig. 4).

The foregoing results is fully agree with the findings of Al- Beltagy et al. (1995), who studied the relationships between PBW trap catches and boll infestation under different conditions. Their results indicated that the correlation between PBW trap catches and PBW infestation in open bolls was of great importance in predicting the population of this insect. Moreover, Qureshi et al. (1993) used male adult catches in gossyplure-baited traps to predict infestation of pink bollworm. They suggested that the catches were positively correlated with the percentage of larval infestation. Also, Buchelos et al. (1999) mentioned that there was a significant positive linear correlation between the number of moths caught and the infestation percentage with first and second larval stage on the first $(r=0.69)$ and second $(r=0.7399)$ boll feeding generations. Ismail et al. (2002) showed that an obvious correlation between the number of $P$. gossypiella males caught during May and the size of the population during the following months. 
El-Kady, H. A. et al.

Fig4 
Thus, it could be fairly concluded that positive and significant relationship exists between the average number of males caught in pheromone traps and the rate of infested green bolls, number of larvae /100 bolls and the young larvae (first and second instar) for cotton of different sowing dates. There are different models of the relationship between PBW trap catches and young larvae for different sowing dates.

1.1.4. Relationship between the number of caught males of spiny bollworm (SBW) moths and the percentage of boll infestation

Field trails were carried out to evaluate the relationship between the spiny bollworm, E. insulana male catches in pheromone traps / week and percentages of infested green bolls in cotton fields sown on different dates in successive cotton seasons, 2006, 2007 and 2008.

In 2006 season.

Data presented in Table (1) and illustrated in Fig.(5) indicated a positive and significant relationship between the average numbers of male moths of SBW caught in the pheromone traps and the rate of infested green bolls, the number of all larvae /100 bolls and the number of young larvae (first and second instar), The simple correlation coefficient values were 0.86 $(P=0.002) 0.87(P=0.001)$ and $0.81(P=0.002)$,respectively. The regression equation of average male moths and young larvae of SBW in cotton fields was $Y=0.0004 X^{2}+0.1843 X-0.5462$.Fig.(5).

In 2007 season.

Data presented in Table (2) and illustrated in Fig.(5) indicated a positive and significant relationship between the average numbers of male moths of SBW caught in the pheromone traps and the rate of infested green bolls, the number of all larvae /100 bolls and the number of young larvae (first and second instar). The simple correlation coefficient values were 0.79 $(P=0.002), 0.79(P=0.001)$ and $0.72(P=0.002)$,respectively. The regression equation of average male moths and young larvae of SBW in cotton fields was $Y=0.0018 X^{2}-0.125 X+3.3728$. Fig.(5).

In 2008 season.

Data presented in Table(3) and illustrated in Fig.(5) indicated a positive and significant relationship between the average numbers of male moths of SBW caught in the pheromone traps and the rate of infested green bolls, the number of all larvae /100 bolls and the number of young larvae (first and second instar). The simple correlation coefficient values were 0.68 $(P=0.002), 0.68(P=0.001)$ and $0.68(P=0.002)$, respectively. The regression equation of average male moths and young larvae of SBW in cotton fields was $Y=-0.0004 X^{2}-0.0019 X+0.1069$. Fig.(5).

Tawfik (2002) studied the relationship between the population density of spiny bollworm and the infestation level in cotton green bolls. Results indicated that there is a significant positive relationship between the population of SBW moths and the percentage of infestation in cotton green bolls. 
El-Kady, H. A. et al.

Fig5

538 
1.1.5. Effect of prevailing weather factors (temperature and relative humidity) on the population dynamics of both bollworms.

The effect of the prevailing weather factors on the seasonal abundance of cotton bollworms was studied under field conditions at BeniSuef Governorate during three successive seasons, 2006, 2007 and 2008.

\subsubsection{The Pink bollworm (PBW).}

The data presented in Table (4) showed the correlation between the pink bollworm population and weather factors (maximum and minimum temperature and average relative humidity). It was obvious that the simple correlation coefficient between the average number of captured male moths in sex pheromone traps and max. temperature was significantly positive with values of $0.42(P=0.03), 0.48(P=0.02)$ in 2006 and 2007, respectively, while in 2008 season, the simple correlation was positive and highly significant $0.72(P=0.001)$. Moreover, the multiple regression analysis revealed that the max. temperature was responsible of 17.6, 23.04 and $51.8 \%$ of the population changes of pink bollworm moths during the above mentioned seasons, respectively. The simple correlation coefficient between the night min. temperature and the population dynamics of pink bollworm was positive and highly significant $0.53(P=0.005)$ and $0.33(P=0.138)$ during the 2006 and 2007 seasons, however in the 2008 season, this relationship was positive and insignificant $0.70(\mathrm{P}=0.001)$. The $\mathrm{min}$. temperature was responsible for $28.1,10.89$ and $49.0 \%$ of the population fluctuations in the three seasons 2006, 2007 and 2008, respectively. The simple correlation coefficient values for the daily mean relative humidity (R.H. \%) with the population density of pink bollworm was positive and insignificant in the three mentioned seasons. The R.H. \% was responsible of $4.84,0.26$ and $10.43 \%$ of the population's changes of pink bollworm during the three seasons, respectively.

The combined effect of the three main weather factors on the changes in the population activity of the pink bollworm moths explained by the percentages of variance of the three tested weather factors were significant during 2006 and highly significant during 2007, respectively, but in 2008 insignificant.

\subsubsection{The spiny bollworm (SBW):}

The data presented in Table (4) showed the correlation between the spiny bollworm population and the weather factors (maximum and minimum temperature and average relative humidity). It was obvious that the simple correlation coefficient between the average numbers of captured male moths in sex pheromone traps and max temperature was insignificant with values of $0.22(P=0.28), 0.25(P=0.25)$ in 2006 and 2008 seasons, while in 2007 seasons, the simple correlation was significant $0.38(P=0.08)$. The multiple regression analysis revealed that the max. temperature was responsible of $4.8,14.4$ and $6.25 \%$ of the population changes of spiny bollworm moths during the above mentioned seasons, respectively. The simple correlation coefficient between the min. temperature and the population dynamics of spiny bollworm was insignificantly positive during the three mentioned seasons. The min. temperature was responsible for $6.3,1.0$ and $1.44 \%$ of the population fluctuations in the three seasons, respectively. The simple correlation coefficient values of the daily mean relative humidity (R.H. \%) with 
the population density of spiny bollworm was positive and insignificant in the three seasons. The R.H. \% was responsible of $0.49,16.89$ and 4.84 of the population changes of spiny bollworm during the three seasons, respectively.

Table (4): Simultaneous effects of weather factors on the population density of $P$. gossypiella,(PBW) andE. Insulana,(SBW) at Sids Agric. Research Station, Beni-Suef Governorate during cotton seasons 2006, 2007and 2008.

\begin{tabular}{|c|c|c|c|c|c|c|c|c|c|c|c|}
\hline \multirow{3}{*}{ Seasons } & \multirow{3}{*}{$\begin{array}{l}\text { Weather } \\
\text { factors }\end{array}$} & \multicolumn{3}{|c|}{ Simple correlation } & \multicolumn{4}{|c|}{ Multiple regression } & \multicolumn{3}{|c|}{ Analysis of variance } \\
\hline & & $r$ & $p$ & E.V.\% & $\mathrm{b}$ & S.E. & $t$ & $p$ & $\mathrm{~F}$ & $p$ & E.V.\% \\
\hline & & \multicolumn{10}{|c|}{$P$. gossypiella } \\
\hline \multirow{4}{*}{2006} & Max., tem. & 0.42 & 0.034 & 17.6 & 0.718 & 1.08 & 0.67 & 0.513 & 3.08 & 0.049 & 29.6 \\
\hline & Min., tem. & 0.53 & 0.005 & 28.1 & 1.706 & 1.275 & 1.34 & 0.195 & & & \\
\hline & R.H.\% & 0.22 & 0.274 & 4.84 & 0.381 & 1.049 & 0.36 & 0.720 & & & \\
\hline & Total & & & 50.54 & & & & & & & \\
\hline \multirow{4}{*}{2007} & Max., tem. & 0.48 & 0.024 & 23.04 & 8.57 & 4.21 & 2.04 & 0.057 & 2.29 & 0.113 & 27.6 \\
\hline & Min., tem. & 0.33 & 0.138 & 10.89 & 3.81 & 4.90 & 0.78 & 0.447 & & & \\
\hline & R.H.\% & 0.051 & 0.822 & 0.26 & 2.60 & 2.42 & 1.07 & 0.297 & & & \\
\hline & Total & & & 34.19 & & & & & & & \\
\hline \multirow{4}{*}{2008} & Max., tem. & 0.72 & 0.001 & 51.8 & 1.73 & 1.58 & 1.09 & 0.29 & 8.51 & 0.001 & \begin{tabular}{|l|}
58.7 \\
\end{tabular} \\
\hline & Min., tem. & 0.70 & 0.001 & 49.0 & 0.98 & 1.73 & 0.57 & 0.58 & & & \\
\hline & R.H.\% & 0.323 & 0.142 & 10.43 & 1.66 & 1.04 & 1.60 & 0.13 & & & \\
\hline & Total & & & 111.2 & & & & & & & \\
\hline \multicolumn{12}{|c|}{ E. insulana } \\
\hline \multirow{4}{*}{2006} & Max., tem. & 0.22 & 0.280 & 4.80 & 0.732 & 2.23 & 0.33 & 0.75 & 0.55 & 0.65 & 7.0 \\
\hline & Min., tem. & 0.25 & 0.212 & 6.3 & 1.49 & 2.63 & 0.57 & 0.58 & & & \\
\hline & R.H.\% & 0.07 & 0.729 & 0.49 & 0.024 & 2.16 & 0.01 & 0.99 & & & \\
\hline & Total & & & 11.58 & & & & & & & \\
\hline \multirow{4}{*}{2007} & Max., tem. & 0.38 & 0.081 & 14.4 & -5.12 & 2.97 & 1.72 & 0.102 & 2.61 & 0.083 & 30.3 \\
\hline & Min., tem. & 0.1 & 0.996 & 1.0 & 3.58 & 3.46 & 1.04 & 0.314 & & & \\
\hline & R.H.\% & 0.411 & 0.057 & 16.89 & 1.07 & 1.71 & 0.62 & 0.540 & & & \\
\hline & Total & & & 32.39 & & & & & & & \\
\hline \multirow{4}{*}{2008} & Max., tem. & 0.25 & 0.257 & 6.25 & 4.26 & 2.44 & 1.74 & 0.09 & 1.45 & 0.261 & 19.5 \\
\hline & Min., tem. & 0.12 & 0.582 & 1.44 & -3.88 & 2.68 & 1.45 & 0.164 & & & \\
\hline & R.H.\% & 0.22 & 0.324 & 4.84 & 1.36 & 1.60 & 0.85 & 0.405 & & & \\
\hline & Total & & & 12.53 & & & & & & & \\
\hline
\end{tabular}

The combined effect of the three main weather factors on the changes in the population activity of the pink bollworm moths explained by the percentages of variance of the three tested weather factors was significant during 2007, but in 2006 and 2008 insignificant.

Reviewing the aforementioned results, it could be stated, that our findings agree with those obtained by Hussien (1990) who mentioned that the effect of the daily relative humidity was insignificant on both pink and spiny bollworms. Nassef (1989) concluded that the combined effect of the prevailing relative humidity had a slight effect on the flight activity of male moths of pink bollworm. Gupta et al. (1996) used sex pheromone traps to study the population dynamics of cotton pests in Madhya Pradesh, India, in 1989-90 and 1990-91. The maximum temperature showed a significant 
negative correlation with trap catches and relative humidity showed a significant positive correlation with trap catches. Also, Dhawan and Simwat (1996) mentioned that the relationship of pink bollworm catch with weather parameters was positive and insignificant.

\section{REFERENCES}

Abdel-Hamid, Z. H., S. M. El -Fateh, G. B. El-Saadany and M. A. Romeila (1999). Approximate number of annual field generations of pink bollworm, Pectinophora gossypiella ( Saunders). Egypt. J. Agric. Res., 77 (2) : 575- 589.

Al- Beltagy, A. M., A. M. Hamid and A. A. Salem (1995). Efficiency of nine different control techniques (pheromone and or insecticides) on pink bollworm, trap catches and boll infestation $.1^{\text {st }}$ Int. Conf. of Pest Control, Mansoura, Egypt, Sept. 1995. pp. 197- 205.

Barania, E. M. H. (1979). Studies on some cotton pests. M. Sc. Thesis, Alexandria Univ.

Buchelos, C. T., C. G. Athanassiou, C. C. Papapostolou and M. W. Georgious (1999). Correlation between the number of adult male Pectinophora gossypiella (Saund.) (Lep., Gelechidae) catches on pheromone traps and rate of infestation in fruiting bodies of cotton plants by young larvae in three regions of central Greece. J. Applied Ent., 123, 433-436.

Dhawan, A. K. and G. S. Simwat (1996). Monitoring the seasonal abundance of cotton bollworms with pheromone traps. Indian Journal of Ecology. 23 (2): 123-129.

El - Zanan, A. A. (1987). Studies on the bollworm. Ph. D. Thesis. Fac. of Agric. Kafr El - Sheikh. Tanta Univ.

Gupta, G.P., K. Sharma and K. Sharma (1996). Utilization of biopesticides in managing the cotton pest complex in India. Proceedings Beltwide Cotton Conferences, Nashville, TN, USA, January 9-12, 1996: Volume 2. $1996,1135-1140$.

Hamid, A. R. and A. M. Al- Beltagy (1995). Mass- trapping technique for pink bollworm control . $1^{\text {st }}$ Int. Conf. of pest control, Mansoura Egypt. Sept. 1995. pp. 189-195.

Hossain, A. M., G. B. El-Sadaany, Z. H. Abdel- Hamid and M. A. Romeilah (1999). Estimated number and duration of spiny bollworm, Earias insulana (Boisd.) field generations. Egypt. J. Agric. Res., 77 (2) : 631 645.

Hussien, N. M. (1990). Studies on the effect of some weather factors on the population activity of bollworm at Fayoum Governorate. Ph. D. Thesis. Fac. Agric. Ain Shams Univ. Cairo Egypt.

Ismail, I. I., S. A. Emara, M. Y. Hashem and H. F. Dahi (2002). Flight activity of Pectinophora gossypiella ( Saund.) Lepidoptera: Gelechiidae moths in cotton fields at Menoufia Governorate, Egypt. ${ }^{\text {nd }}$ international Conference, Plant Protection Research Institute, Cairo, Egypt, 21- 24 December. 
El-Kady, H. A. et al.

Jutsum, A. R. and Gordon, R. F. S. (1989). Insect pheromones in plant protection. John Wiley and Sons Ltd. New York, pp. 369.

Kumar, K. K. and Devaraj Urs, K. C. (1991). Evaluation of pheromone virgin female traps monitoring Earias vitella on bhendi. Indian J. Entomol., 53(2): 232- 239.

Mcaughlin, J. R. and Mitchel, E. R. (1982). Practical development in Heliothis management. Proceeding of the International Workshop on Heliothis armigera ICRISAT, pp.309-318.

Moawad, G. M. (1974). Effect of certain species of bollworms, Pectinophora gossypiella (saund.) and Earias insulana (Boisd.) on cotton plants and yield in relation to agriculture practices. Ph. D. Thesis, Fac. of Agric., El- Azhar Univ.

Mohamed, E. M. (2004). New Approaches for control of cotton bollworms. Ph. D. Thesis, Department of Economic Entomology and Pesticides Faculty of Agriculture, Cairo University.

Nassef, M. A. (1989). Integrated control of pink bollworm, Pectinophora gossypiella (Saund.). M. Sc. Thesis, Fac. of Agric. Zagazig Univ.

Othman, K. S. A., M. A. Kandil, S. M. Dogheim and A. M. Sami (2000). Analysis and persistence of the Pectinophora gossypiella synethetic sex pheromone ( PB-ROPES) under field conditions. $1^{\text {st }}$ international Conf. of applied Entoml., Fac. of Sci., Cairo Univ. , 10-12 March 2000, 113- 127.

Qureshi, Z. A., N. Ahmed and T. Hussain (1993). Pheromone trap catches as a means of predicting damage by pink bollworm larvae in cotton. Crop Protection, 12 (8): 597-600.

Shaaban, A. M. and H. S. Radwan (1974). Population dynamics of the pink bollworm, Pectinophora gossypiella (Saund.) in relation to blooming and fruiting curves of cotton plants. Pflanzen krankheiten , 4: 206- 211.

Tawfik, S. M. (2002). The relationship between the population density of spiny bollworm, Earias insulana (Boisd.) and the infestation levels in the cotton green bolls. $2^{\text {nd }}$ International Conf. , Plant Protection Res. Institute, Cairo, Egypt, 21-24 December, 1: 774-778.

Toscano, N. C., Mueller, A. J., Sevacherian, V., Sharma, R. K., Niilus, T. and Reynolds, H. T. (1974). Insecticide applications based on hexalure trap catches versus automatic schedule treatments for pink bollworm moth control. J. econ. Ent., 67: 522-524. 


\section{العلاقة بين تعداد فراشات الذكور في المصـائد الفرمونية ونسبة الاصسابة في اللوز

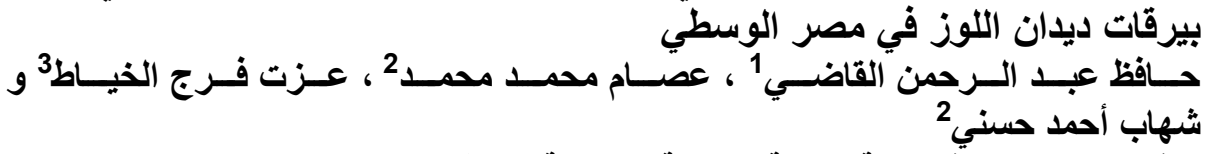

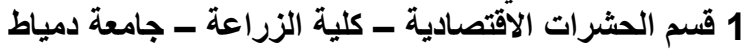

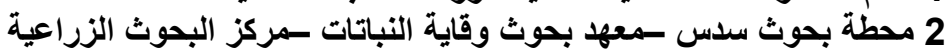

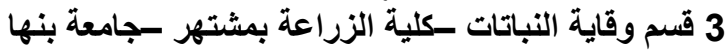

تمت هذه الدراسة تحت الظروف الحقلية بمحطة سدس للبحوث الزر اعية بمحافظة بنـي سويف

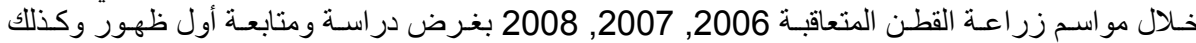

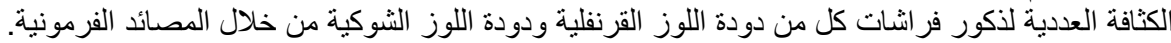

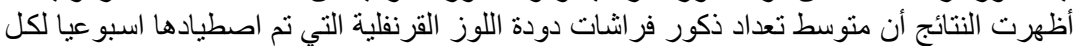

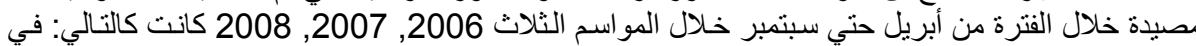

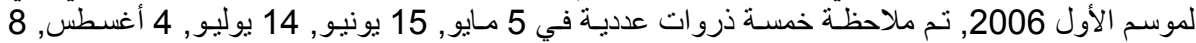

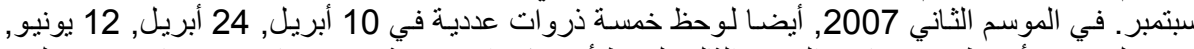

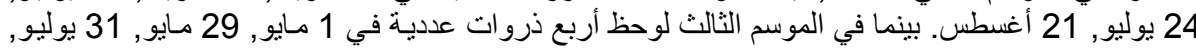

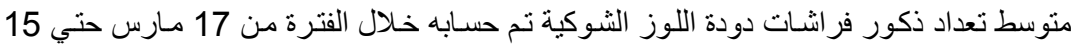

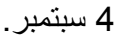

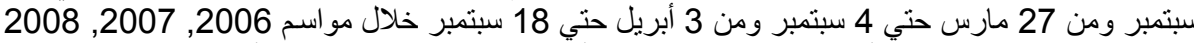

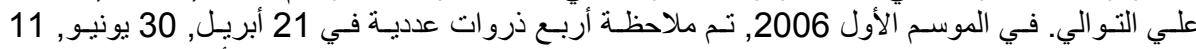

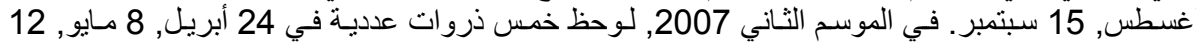
يونيو, 24 يوليو, 28 أغطس. بينما في الموسم الثالث لوحظ أربعة ذروات لئر عددية في 1 مايو, 31 يوليو, 4

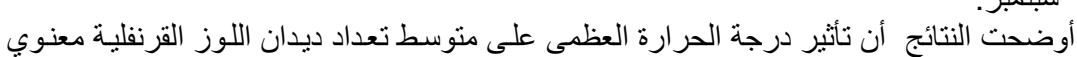
سبتمبر, 18 سبتمبر .

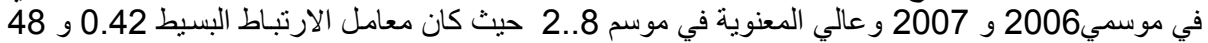

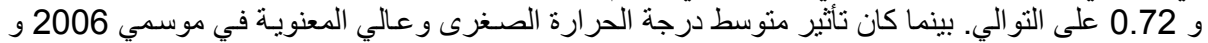

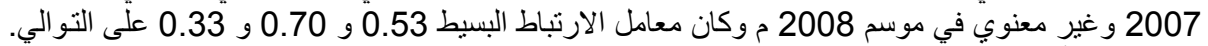

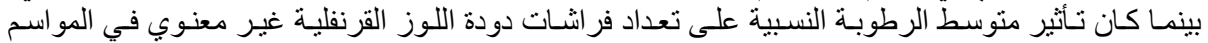

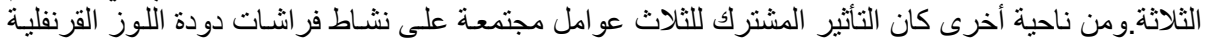

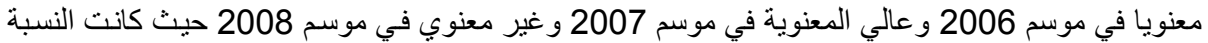

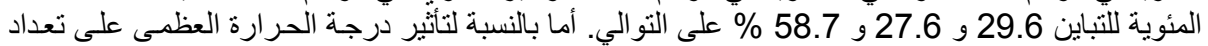

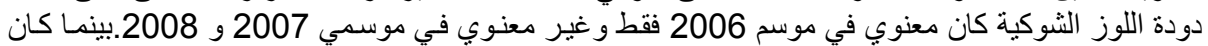

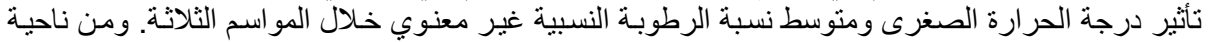

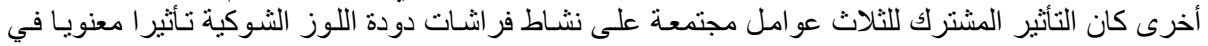
موسم 2006 و غير معنوي في موسمي 2007 و 2008 حيث كانت النسبة المئوية للتباين 7.0 و و 30.3 و

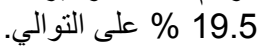

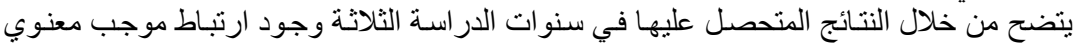

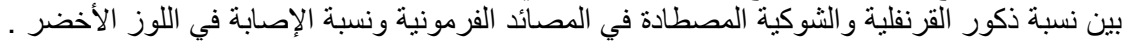

كلية الزراعة - جامعة المنصورة

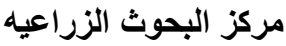

